
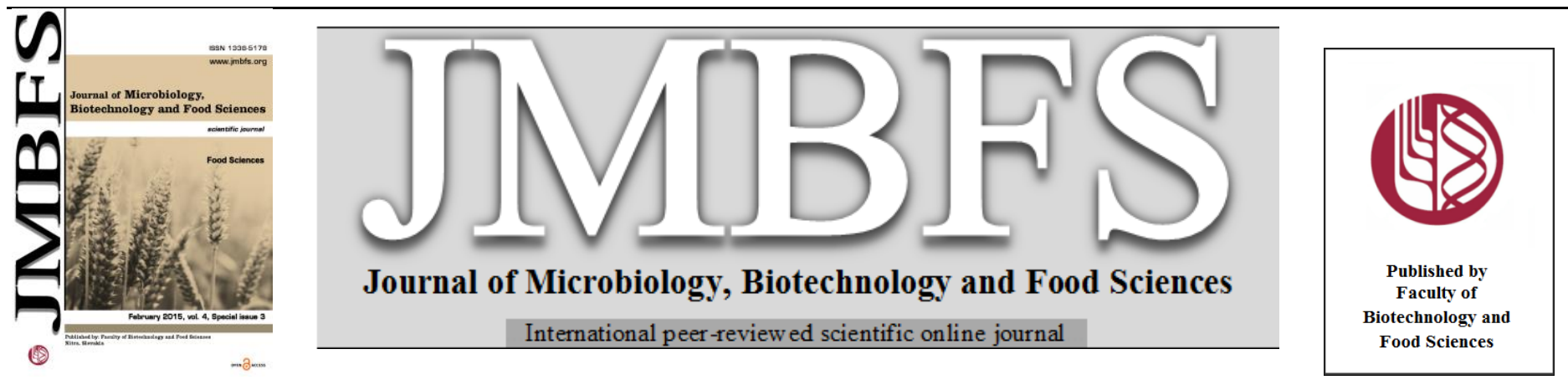

\title{
EFFECT OF BEE POLLEN DIETARY SUPPLEMENTATION ON MEAT PERFORMANCE OF ROSS 308 BROILER CHICKENS
}

\author{
Peter Haščík ${ }^{\prime}$, Lenka Trembeckál, Jana Tkáčová ${ }^{l}$, Miroslav Kročko, Juraj Čuboñ ${ }^{1}$, Miroslava Kačániová2
}

Address(es): doc. Ing. Peter Hašč́k, PhD.

${ }^{1}$ Slovak University of Agriculture in Nitra, Faculty of Biotechnology and Food Sciences, Department of Animal Products Evaluation and Processing, Tr. A. Hlinku 2, 94976 Nitra, Slovak Republic.

${ }^{2}$ Slovak University of Agriculture in Nitra, Faculty of Biotechnology and Food Sciences, Department of Microbiology, Tr. A. Hlinku 2, 94976 Nitra, Slovak Republic.

*Corresponding author:peter.hascik@uniag.sk

doi: 10.15414/jmbfs.2015.4.special3.55-58

\section{ARTICLE INFO}

Received 2. 12. 2014

Revised 10. 12. 2014

Accepted 11. 12. 2014

Published 2. 2. 2015

Regular article OPEN $\partial_{\text {ACCESS }}$

\section{ABSTRACT}

A present study was conducted to evaluate the effect of dietary inclusion of bee pollen extract on meat performance of Ross 308 broiler chickens. A total of 180 one day-old Ross chicks were involved in experiment. Chickens were divided into 2 groups, an experimental group (E) and a control group (C). No added supplement was given to the control group, while the experimental group was given the feed mixture supplemented with bee pollen in an amount of $400 \mathrm{mg} \cdot \mathrm{kg}^{-1}$, during the whole fattening period. Data of live body weight, carcass weight, giblets weight and carcass yield were determined at 42 days of the age. The supplementation of bee pollen increased final body weight of broilers by $68.5 \mathrm{~g}$. Each of investigated parameters of meat performance in experimental group was higher to that in control group, although the difference among the groups was not statistically significant $(\mathrm{P} \geq 0.05)$. The addition of bee pollen at dose $400 \mathrm{mg} \cdot \mathrm{kg}^{-1}$ in the feed mixture indicates the slight effect on meat performance of chickens which can be beneficial for fattening of broiler chickens.

Keywords: Meat performance, bee polen, Ross 308, broiler

\section{INTRODUCTION}

Antibiotics have been widely used in animal production for decades. Although some are used therapeutically to improve the health and well-being of animals, most were given for prophylactic purposes and to improve growth rate and feed conversion efficiency (as antimicrobial growth performance promoters, AGPs) (Huyghebaert et al., 2011). However, there is the fear that the continuous subtherapeutic use of in-feed antibiotics could lead to the development of antibiotic resistant bacteria, which can be harmful to humans (Nasir and Grashorn, 2006). Thus, efforts have been made in different parts of the world to ban the inclusion of all types of antibiotic growth promoters in animal feeds (Landy et al., 2011). Due to the emergence of microbes resistant to antibiotics which are used to treat human and animal infections, the European Commission (EC) decided to phase out, and ultimately ban, the marketing and use of antibiotics as growth promoters in feed (Regulation (EC) No. 1831/2003).

The impact of phasing out animal growth promoters could be minimized provided that adequate attention is given to the implementation of alternative disease-prevention strategies and management factors, such as alternative husbandry practices in food animal production (Toghyani et al., 2010), especially in poultry production (Diarra et al., 2007; Attia et al., 2014). Some of the measures implemented have demonstrated to be efficacious and helped to maintain animal productivity at levels close to the ones observed when antibiotics were used in feed (Castanon, 2007).

After ban of feed antibiotics in animal industry in 2006, poultry industry has adapted by improving selective breeding, biosecurity and management practices, environmental control of livestock facilities and introducing changes in birds feed composition and feeding programs (Da Costa et al., 2011). Many natural substances used as alternatives to antibiotic in animal feed have been shown to express positive effects on growth performance and different health parameters (Hong et al., 2012; Thiamhirunsopit et al., 2014).

During the past two decades, the poultry industry has been one of the most dynamic and ever expanding sectors in the world. It helps to fill the gap between requirement and availability of high quality protein for human consumption. The demand for a higher and safer protein source, free of infectious agents, is getting increased (Pelicano et al., 2004; Alkhalf et al., 2010). Poultry meat is one of the most important foods in many cultures around the world, due to its nutritional characteristics. Carcass evaluation should be considered an important part of poultry-processing activities because it involves observation of standards of quality for the birds according to grading and expected yield. However, carcass composition can change under certain circumstances, such as stress, diet, preslaughter handling, the slaughtering process, genetic factors, and more. Genetics has been a major contributor to carcass yield increase, following advances in poultry nutritional knowledge. As carcass yield is such an important factor in the poultry industry from an economic point of view, many efforts have been made to predict it (Durán-Meléndez, 2010).

Broiler chickens are characterized by a very fast growth rate; therefore diet of broilers should contain high concentrations of available nutrients (Zimnoch $\boldsymbol{e t}$ al., 2000). What is more, composition of feed mixtures for chickens is important in terms of the required ratio between nutrients and energy. Therefore, the evaluation of nutrition supplements designed for feed mixtures is an abiding interest to improve the carcass yield, health and final quality of poultry meat. One of possible alternatives is to use plant-derived substances, which received considerable interest by the poultry industry, because of their antioxidant and antimicrobial effects (Attia et $\boldsymbol{a l}$., 2014) and favorable effect on meat performance, as well (Touhy et al., 2005).

Bee pollen (BP) is one of plant-derived substances. It is an agglomerate of flower pollen collected by bees, mixed with nectar and secretions from the hypofaryngean glands. It is a rich source of indispensable amino acids, water and fat soluble vitamins, and flavonoids (Oliveira et al., 2013; Attia et al., 2014) and it is considered a health food with a wide range of therapeutic properties, among which: antimicrobial, antifungal, antioxidant, anti-radiation, hepatoprotective, chemoprotective, chemopreventive and anti-inflammatory activities (Pascoal $\boldsymbol{e t}$ al., 2014). The major components of $B P$ are carbohydrates, crude fibers, proteins and lipids at proportions ranging between 13 and $55 \%, 0.3$ and $20 \%, 10$ and $40 \%, 1$ and $10 \%$, respectively. Other minor components are minerals and trace elements, vitamins and carotenoids, phenolic compounds, flavonoids, sterols and terpenes (Feás et al., 2012). The composition of bee pollen depends strongly on plant source, together with other factors such as climatic conditions, soil type, and beekeeper activities (Morais et al., 2011).

The quantity and quality of pollen collected by honeybees affects reproduction, brood rearing and longevity, thus ultimately the productivity of the colony (Human and Nicolson, 2006). The protein content of pollen is considered a direct and reliable measure of its nutritional value. Amino acid composition, however, may define the nutritional value of pollen more accurately than protein 
content, since the nutritional value is reduced as soon as inadequate amounts of the essential amino acids (Cook et al., 2003; Human and Nicolson, 2006).

The objective of the present work was to assess the effect of bee pollen extract as a dietary supplement on meat performance of Ross 308 broiler chickens.

\section{MATERIAL AND METHODS}

The experiment was implemented in the test poultry station of Slovak University of Agriculture in Nitra. A total of 180 one day-old Ross 308 broiler chicks were randomly assigned to 2 groups. The groups were as follows: control (C) and experimental (E). The experiment lasted for 42 days and it was carried out without segregation between the genders. The broiler chickens were bred in a cage conditions and had ad libitum access to feed and water. They were raised in a temperature-controlled room; the temperature began at $33{ }^{\circ} \mathrm{C}$ and was decreased gradually to $19{ }^{\circ} \mathrm{C}$ until the end of the experiment. The lighting regime was steady during the feeding period.

Experimental broiler chickens were fed during 42 days of age with starter complete feed mixture HYD-01 (until the age of 21st days) and grower feed mixture HYD-02 (from 22nd to 42nd days of age). The composition of feed mixtures is given Table 1. The feed mixtures both starter and grower were produced without any antibiotic preparations and coccidiostatics. Nutrients content and metabolizable energy in feed mixtures were balanced, in terms broiler chickens needs (Vestník MP SR, 2005). Both groups, control and experimental, were fed with the same feed mixtures, except that the pollen extract in amount of $400 \mathrm{mg} \cdot \mathrm{kg}^{-1}$ was added to feed mixtures (HYD-01 and HYD-02) given to experimental group. The groups were otherwise kept under the same conditions.

Bee pollen had origin in the Slovak Republic. Bee pollen extract was prepared from minced bee pollen in the conditions of the $80 \%$ ethanol in the $500 \mathrm{~cm}^{3}$ flasks, according to Krell (1996). The extraction was accomplished in a water bath at $80{ }^{\circ} \mathrm{C}$ for one hour. After that the extract was cooled and centrifuged. The obtained supernatant was evaporated in a rotary vacuum evaporator at bath temperature $\quad 40-50{ }^{\circ} \mathrm{C}$ and weighed. Residue in an amount of $80 \mathrm{~g}$ was dissolved in $1000 \mathrm{~cm}^{3}$ of $80 \%$ ethanol and used for $100 \mathrm{~kg}$ of feed mixture.

The live body weight of broiler chickens was determined in the test poultry station of Slovak University of Agriculture in Nitra. For the slaughtering, a tota of 120 broiler chickens were chosen from both control and experimental group $(\mathrm{n}=60)$. The results of meat performance (arithmetic mean, standard deviation, minimum, maximum, coefficient of variation) were processed by the statistic program Statgraphics 5.1. For the determination of significant differences between the tested groups, F-test was used followed by t-test.

Table 1 Composition of feed mixtures

\begin{tabular}{|c|c|c|}
\hline Ingredients (\%) & $\begin{array}{c}\text { Starter HYD-01 } \\
(1 .-21 . \text { day of age })\end{array}$ & $\begin{array}{c}\text { Grower HYD-02 } \\
(22 .-42 . \text { day of age })\end{array}$ \\
\hline Wheat & 35.00 & 35.00 \\
\hline Maize & 35.00 & 40.00 \\
\hline Soybean meal (48 \% N) & 21.30 & 18.70 \\
\hline Fish meal $(71 \% \mathrm{~N})$ & 3.80 & 2.00 \\
\hline Dried blood & 1.25 & 1.25 \\
\hline Ground limestone & 1.00 & 1.05 \\
\hline Monocalcium phosphate & 1.00 & 0.70 \\
\hline Fodder salt & 0.10 & 0.15 \\
\hline Sodium bicarbonate & 0.15 & 0.20 \\
\hline Lysine & 0.05 & 0.07 \\
\hline Methionine & 0.15 & 0.22 \\
\hline Palm kernel oil Bergafat & 0.70 & 0.16 \\
\hline Premix Euromix BR $0.5 \%{ }^{*}$ & 0.50 & 0.50 \\
\hline \multicolumn{3}{|l|}{ Nutrient composition [g. kg $\left.{ }^{-1}\right]$} \\
\hline Crude protein & 210.76 & 190.42 \\
\hline Fibre & 30.19 & 29.93 \\
\hline Ash & 24.24 & 19.94 \\
\hline $\mathbf{C a}$ & 8.16 & 7.28 \\
\hline $\mathbf{P}$ & 6.76 & 5.71 \\
\hline Mg & 1.41 & 1.36 \\
\hline Linoleic acid & 13.51 & 14.19 \\
\hline $\mathrm{ME}_{\mathrm{N}}\left[\mathrm{MJ} . \mathrm{kg}^{-1}\right]$ & 12.02 & 12.03 \\
\hline
\end{tabular}

*active substances per kilogram of premix: vitamin A $2500000 \mathrm{IU}$; vitamin E $50000 \mathrm{mg}$; vitamin D3 800000 IU; niacin $12000 \mathrm{mg}$; d-pantothenic acid 3 000 $\mathrm{mg}$; riboflavin $1800 \mathrm{mg}$; pyridoxine $1200 \mathrm{mg}$; thiamine $600 \mathrm{mg}$; menadione $800 \mathrm{mg}$; ascorbic acid $50000 \mathrm{mg}$; folic acid $400 \mathrm{mg}$; biotin $40 \mathrm{mg}$; vitamin B12 10.0 mg; choline 100000 mg; betaine 50000 mg; Mn 20000 mg; Zn 16000 mg; Fe 14000 mg; Cu 2400 mg; Co 80 mg; I 200 mg; Se 50 mg

\section{RESULTS AND DISCUSSION}

The results of experiment with Ross 308 broiler chickens are given Table 2. As the results were not reported as statistically significant, hardly any of investigated parameters represented in Table 2 (live body weight, carcass weight, giblets weight and carcass yield) were completely affected by dietary treatments. Despite insignificant increase $(\mathrm{P} \geq 0.05)$ in body weight $(68.5 \mathrm{~g})$ of group fed diet containing BP extract at the end of the trial (2338.70 g) compared to the control treatment $(2270.20 \mathrm{~g})$, it can be enounced that BP has positive effect on weigh increase as well as the carcass weight (1629.80 $\mathrm{g}$ for $\mathrm{C}$ group, $1699 \mathrm{~g}$ for $\mathrm{E}$ group) and giblets weight (152.08 $\mathrm{g}$ for $\mathrm{C}$ group, $155.39 \mathrm{~g}$ for $\mathrm{E}$ group). Carcass yield in experimental group $(79.30 \%)$ was also higher than control group $(78.54$ $\%$ ).

Table 2 Effect of bee pollen on meat performance parameters of Ross 308 broiler chickens

\begin{tabular}{lcccccccc}
\hline \multicolumn{1}{c}{ Parameter } & \multicolumn{2}{c}{ Live body weight (g) } & \multicolumn{2}{c}{ Carcass weight (g) } & \multicolumn{2}{c}{ Giblets weight (g) } & \multicolumn{2}{c}{ Carcass yield (\%) } \\
\hline Group C & Group E & Group C & Group E & Group C & Group E & Group C & Group E \\
\hline $\mathbf{n}$ & 60 & 60 & 60 & 60 & 60 & 60 & 60 & 60 \\
SD & 2270.20 & 2338.70 & 1629.80 & 1699 & 152.08 & 155.39 & 78.54 & 79.30 \\
min. & 107.88 & 111.10 & 73.64 & 89.34 & 19.83 & 15.29 & 1.41 & 1.48 \\
max. & 2045 & 2171 & 1497 & 1570 & 106.61 & 125.92 & 75.97 & 76.39 \\
CV $(\%)$ & 2395 & 2479 & 1756 & 1830 & 184.71 & 182.11 & 80.96 & 81.15 \\
SS & 4.75 & 4.75 & 4.56 & 5.26 & 13.04 & 9.84 & 1.80 \\
\hline
\end{tabular}

Legend: $\mathrm{C}$ - control group, $\mathrm{E}$ - experimental group, $\mathrm{n}$ - number of broiler chickens, $\mathrm{x}$ - arithmetic mean, $\mathrm{SD}$ - standard deviation, min. - minimum, max. maximum, $\mathrm{CV}$ - coefficient of variation, $\mathrm{SS}$ - statistical significance

Several studies claimed positive effect of bee pollen on growth, performance and internal milieu of broiler chickens (Villanueva et al., 2002; Wang et al., 2007; Cheng, 2009; Haščík et al., 2011, 2012, 2013; Hashmi et al., 2012; Kačániová et al., 2013). Wang et al. (2007) found enhancing calcium absorption and, subsequently, its deposition in the bones after addition of BP. They also attained to finding that bee pollen-supplemented diet raised the body weight of broiler chickens of $35.1 \%$ (1585.67 g) compared to control group (1173.33 g). Haščík et al. (2013) deduced that the addition of BP in diet of Ross 308 broiler chickens led to an increase of the water content in breast muscles, whereas the protein content, fat content and energy value in breast muscles was decreased. In study of Hashmi et al. (2012) was observed weight increase in the economic parts of chicken meat (carcass, thighs, breast, liver, gastric and heart) after BP addition in an amount of $5 \mathrm{~g}_{\mathrm{kg}} \mathrm{kg}^{-1}$ of feed mixture (while higher amount of BP had negative impact). Positive effect of bee pollen as a dietary supplement in feed mixture of broiler Ross 308 in amount of $400 \mathrm{mg} \cdot \mathrm{kg}^{-1}$ was determined by Hašćík et al. (2012) due to increase of carcass values (live body weight, carcass weight, giblet 
weight and carcass yield) in males. These authors found that the live body weight was increased by $55.40 \mathrm{~g}$, the carcass weight was increased by $41 \mathrm{~g}$, the giblets weight was increased by $4.09 \mathrm{~g}$ and carcass yield was increased by $0.08 \%$. All these increases were insignificant $(\mathrm{P} \geq 0.05)$, as well as in our experiment. On the contrary, live body weight (and the other parameters too) of female chicken group was increased by $52.2 \mathrm{~g}$. It might be caused by BP activity on the reproductive female hormones, as they mention. Angelovičová et al. (2010) who also observed the addition of BP $(0.10 \%)$ in broiler chickens diet found out the positive impact of BP on body weight by about $65.05 \mathrm{~g}$ (similar to that increase of weight in our experiment).

\section{CONCLUSION}

The addition of bee pollen to the feed mixture for Ross 308 broiler chickens in amount of $400 \mathrm{mg} \cdot \mathrm{kg}^{-1}$ without segregation between genders; resulted in insignificant $(\mathrm{P} \geq 0.05)$ changes of meat performance. However, all investigated parameters (live body weight, carcass weight, giblet weight and carcass yield) of meat performance in experimental group were raised as compared with contro group of broiler chickens (without addition of bee pollen). Supplementing bee pollen had positive effect on growth performance, but it would be appropriate to carry out further experiments.

Acknowledgments: This work was supported by VEGA 1/0129/13.

\section{REFERENCES}

ALKHALF, A., ALHAJ, M., AL-HOMIDAN, I. 2010. Influence of probiotic supplementation on blood parameters and growth performance in broiler chickens. Saudi Journal of Biological Sciences, 17 (3), 219-225 http://dx.doi.org/10.1016/j.sjbs.2010.04.005

ANGELOVIČOVÁ, M., ŠTOFAN, D., MOČÁR, K., LIPTAIOVÁ, D. 2010 Biological effects of oilseed rape bee pollen and broiler's chickens performance. International conference on food innovation, Universidad politechnica de Valencia, Spain, 246-247.

ATTIA, Y. A., ABD AL-HAMID, A. E., IBRAHIM, M. S., AL-HARTHI , M. A., BOVERA, F., ELNAGGAR, A. S. 2014. Productive performance, biochemical and hematological traits of broiler chickens supplemented with propolis, bee pollen, and mannan oligosaccharides continuously or intermittently. Livestock Science, 164, 87-95. http://dx.doi.org/10.1016/j.livsci.2014.03.005

CASTANON, J. I. R. 2007. History of the use of antibiotic as growth promoters in European poultry feeds. Poultry Science, 86 (11), 2466-2471. http://dx.doi.org/10.3382/ps.2007-00249

CHENG, Y. 2009. Effect of bee pollen on the growth of immune organs of miscellaneous broilers. Animal Husbandry and Feed Science, 2009, 30 (1), 23 24.

COOK, S. M., AWMACK, C. S., MURRAY, D. A., WILlIAMS, I. H. 2003 Are honey bees' foraging preferences affected by pollen amino acid composition? Ecological Entomology, 28 (5), 622 -627. http://dx.doi.org/10.1046/j.13652311.2003.00548.x

DA COSTA, M. P., OLIVEIRA, M., RAMOS, B., BERNARDO, F. 2011. The impact of antimicrobial use in broiler chickens on growth performance and on the occurrence of antimicrobial-resistant Escherichia coli. Livestock Science, 136 (23), 262-269. http://dx.doi.org/10.1016/j.livsci.2010.09.016

DIARRA, M. S., FRED, G. S., FATOUMATA, D., JANE, P., LUKE, M. ROLAND, B., CLAUDIE, B., PASCAL, D., SUSAN, B., BRENT, J. S., EDWARD, T. 2007. Impact of feed supplementation with antimicrobial agents on growth performance of broiler chickens, Clostridium perfringens and Enterococcus counts, and antibiotic resistance phenotypes and distribution of antimicro bial resistance determinants in Escherichia coli isolates. American Society for Microbiology, $73 \quad$ (20), $\quad$ 6566-6576. http://dx.doi.org/10.1128/aem.01086-07

DURÁN-MELÉNDEZ, L. A. 2010. Poultry Carcass Evaluation and Cutting. In Guerrero-Legarreta, I. Handbook of poultry science and technology. Hoboken : Wiley. 2010. p. 101-103. ISBN 978-0-470-18552-0. http://dx.doi.org/10.1002/9780470504451.ch7

FEÁS, X., VÁZQUEZ-TATO, M. P., ESTEVINHO, L., SEIJAS, J. A., IGLESIAS, A. 2012. Organic Bee Pollen: Botanical Origin, Nutritional Value, Bioactive Compounds, Antioxidant Activity and Microbiological Quality. Molecules, 17 (7), 8359-8377. http://dx.doi.org/10.3390/molecules17078359

HAŠČÍK, P., ELIMAM, I. O. E., BOBKO, M., KAČÁNIOVÁ, M., POCHOP, J., GARLÍK, J., KROČKO, M., ČUBOŇ, J., VAVRIŠINOVÁ, K., ARPÁŠOVÁ, H., CAPCAROVÁ, M., BENCZOVÁ, E. 2011. Oxidative stability of chicken meat after pollen extract application in their diet. Journal of Microbiology, Biotechnology and Food Sciences, 1 (1), 70-82.

HAŠČÍK, P., ELIMAM, I., GARLÍK, J., KAČÁNIOVÁ, M., ČUBOŇ, J., BOBKO, M., ABDULLA, H. 2012. Impact of bee pollen as feed supplements on the body weight of broiler Ross 308. African Journal of Biotechnology, 11 (89), $15596-15599$.

HAŠČÍK, P., ELIMAM, I., GARLÍK, J., KAČÁNIOVÁ, M., ČUBOŇ, J., BOBKO, M., VAVRIŠINOVÁ, K., ARPÁŠOVÁ, H. 2013. The effect of bee pollen as dietary supplement on meat chemical composition for broiler Ross 308 . Acta Universitatis Agriculturae et Silviculturae Mendelianae Brunensis, 61, 7176. http://dx.doi.org/10.11118/actaun201361010071

HASHMI, M. S., HAŠČÍK, P., ELIMAN, I., GARLÍK, J., BOBKO, M., KAĆÁNIOVÁ, M. 2012. Effects of Bee Pollen on the Technical and Allocative Efficiency of Meat Production of Ross 308 Broiler. International Journal of Poultry Science, 11 (11), 689-695. http://dx.doi.org/10.3923/ijps.2012.689.695

HONG, J., STEINER, T., AUFY, A., LIEN, T. 2012. Effects of supplemental essential oil on growth performance, lipid metabolites and immunity, intestinal characteristics, microbiota and carcass traits in broilers. Livestock Science, 144 (3), 253-262. http://dx.doi.org/10.1016/j.livsci.2011.12.008

HUMAN, H., NICOLSON, S. W. 2006. Nutritional content of fresh, beecollected and stored pollen of Aloe greatheadii var. davyana (Asphodelaceae) Phytochemistry, 67 (14),

1486-1492. http://dx.doi.org/10.1016/j.phytochem.2006.05.023

HUYGHEBAERT, G., DUCATELLE, R., VAN IMMERSEEL, F. 2011. An update on alternatives to antimicrobial growth promoters for broilers. The

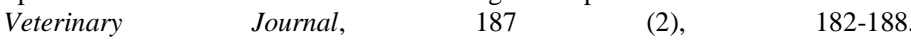
http://dx.doi.org/10.1016/j.tvj1.2010.03.003

KAČÁNIOVÁ, M., ROVNÁ, K., ARPÁŠOVÁ, H., HLEBA, L., PETROVÁ, J. HAŠČÍK, P., ČUBOŇ, J., PAVELKOVÁ, A., CHLEBO, R., BOBKOVÁ, A., STRIČÍK, M. 2013. The effects of bee pollen extracts on the broiler chicken's gastrointestinal microflora. Research in Veterinary Science, 95 (1), 34-37. http://dx.doi.org/10.1016/j.rvsc.2013.02.022

KRELL, R. 1996. Value-added products from bee keeping. Milan, FAO agricultural services no. 124, Publications, 1996, 395 p., ISBN 92-5-103819-8.

LANDY, N., GHALAMKARI, G. H., TOGHYANI, M. 2011. Performance, carcass characteristics, and immunity in broiler chickens fed dietary neem (Azadirachta indica) as alternative for an antibiotic growth promoter. Livestock Science, 142 (1-3), 305-309. http://dx.doi.org/10.1016/j.livsci.2011.08.017

MORAIS, M., MOREIRA, L., FEAS, X., ESTEVINHO, L. M. 2011. Honeybeecollected pollen from five portuguese natural parks: palynological origin phenolic content antioxidant properties and antimicrobial activity. Food and Chemical Toxicology, 49 (5), 1096-1101. http://dx.doi.org/10.1016/j.fct.2011.01.020

NASIR, Z., GRASHORN, M. A. 2006. Use of Black cumin (Nigella sativa) as alternative to antibiotics in poultry diets. 9th Tagung Schweine-und Geflügelernährung, Halle (Saale), Germany, pp. 210-213. ISBN 3-86010-833-6. OLIVEIRA, M. C., SILVA, D. M., LOCH, F. C., MARTINS, P. C., DIAS, D. M. B., SIMON, G. A. 2013. Effect of bee pollen on the immunity and Tibia characteristics in broilers. Brazilian Journal of Poultry Science, 15 (4), 323-328 http://dx.doi.org/10.1590/s1516-635x2013000400006

PASCOAL, A., RODRIGUES, S., TEIXEIRA, A., FEAS, X., ESTEVINHO, L. M. 2014. Biological activities of commercial bee pollens: Antimicrobial, antimutagenic, antioxidant and anti-inflammatory. Food and Chemical Toxicology, 63, 233-239. http://dx.doi.org/10.1016/j.fct.2013.11.010

PELICANO, E. R. L., SOUZA, P. A., SOUZA, H. B. A., LEONEL, F. R., ZEOLA, N. M. B. L., BOIAGO, M. M. 2004. Productive traits of broiler chickens fed diets containing different growth promoters. Brazilian Journal of Poultry Science, 6 (3), 177-182. http://dx.doi.org/10.1590/s1516$635 \times 2004000300008$

REGULATION (EC) No 1831/2003 of the European Parliament and of the Council of 22 September 2003 on additives for use in animal nutrition

THIAMHIRUNSOPIT, K., PHISALAPHONG, C., BOONKIRD, S., KIJPARKORN, S. 2014. Effect of chili meal (Capsicum frutescens LINN.) on growth performance, stress index, lipid peroxidation and ileal nutrient digestibility in broilers reared under high stocking density condition. Animal Feed Science and Technology, 192, 90-100. http://dx.doi.org/10.1016/j.anifeedsci.2014.03.009

TOGHYANI, M., TOGHYANI, M., GHEISARI, A. A., GHALAMKARI, G. H., MOHAMMADREZAEI, M. 2010. Growth performance, serum biochemistry, and blood hematology of broiler chicks fed different levels of black seed (Nigella sativa) and peppermint (Mentha piperita). Livestock Science, 129 (1-3), 173-178. http://dx.doi.org/10.1016/j.livsci.2010.01.021

TUOHY, K. M., ROUZAUD, G. C. M., BRUCK, W. M., GIBSON, G. R. 2005 Modulation of the human gut microflora towards improved health using prebiotics-assessment of efficacy. Current Pharmaceutical Design, 11 (1), 75-90. http://dx.doi.org/10.2174/1381612053382331

VESTNÍK MP SR, 2005. Výnos Ministerstva pôdohospodárstva Slovenskej republiky z 23. marca 2005 č. 2080/2005-100, ktorým sa mení a dopína výnos Ministerstva pôdohospodárstva Slovenskej republiky zo 7. októbra 1997 č. 1497/1/1997 - 100 o kŕmnych surovinách hospodárskych krmivách, v znení neskorších predpisov.

VILLANUEVA, M. T. O., MARQUINA, A. D., SERRANO, R. B., ABELLÁN, G. B. 2002. The importance of bee-collected pollen in the diet: a study of its composition. Food Science and Nutrition, 53 (3), 217-224. http://dx.doi.org/10.1080/09637480220132832

WANG, J., LI, S., WANG, Q., XIN, B., WANG, H. 2007. Trophic effect of bee pollen on small intestine in broiler chickens. Journal of Medicinal Food, 10 (2), 276-280. http://dx.doi.org/10.1089/jmf.2006.215 
ZIMNOCH, L., SZAREK, J., ABCZAK, J., KONWICKI, A. 2000. Effects of feed supplements on morphological pattern of internal organs in broiler chickens.

Zeszyty Naukowe Politechniki Rzeszowskiej, 49, 65-76. 